\title{
Expression, Topography, and Function of Integrin Receptors Are Severely Altered in Keratinocytes from Involved and Uninvolved Psoriatic Skin
}

\author{
Graziella Pellegrini," Michele De Luca, * Giovanni Orecchia," Fiorella Balzac," Ottavio Cremona," Paola Savoia," \\ Ranieri Cancedda," and Pier Carto Marchisio" \\ *Istituto Nazionale per la Ricerca sul Cancro, 16132 Genova, Italy; ${ }^{\ddagger}$ Clinica Dermatologica, Università di Pavia, 27100 Pavia, Italy; \\ "Dipartimento di Genetica, Biologia, e Chimica Medica, Università di Torino, 10126 Torino, Italy; and "Dipartimento di Scienze \\ Biomediche e Oncologia Umana, Università di Torino, 10126 Torino, Italy
}

\begin{abstract}
Psoriasis is a hyperproliferative cutaneous disease of unknown etiology and etiopathogenesis. Alteration of keratinocyte adhesiveness to basal lamina has been proposed as the initial disturbance leading to poorly controlled proliferation. Keratinocyte adhesion to basal lamina and lateral interactions among basal epidermal cells are mediated, besides other molecules, by integrin receptors that are segregated to discrete membrane domains. In this paper, the expression and function of integrins in psoriatic keratinocytes were examined, both in vivo and in vitro. We found that: $(a)$ in psoriatic keratinocytes the integrin heterodimers $\alpha_{2} \beta_{1}, \alpha_{3} \beta_{1}$, and $\alpha_{6} \beta_{4}$ have lost their polarized distribution on the plasma membrane; (b) the role of these integrins in mediating keratinocyte adhesion in vitro is altered; (c) psoriatic keratinocytes form focal contacts containing both $\beta_{1}$ and $\beta_{4}$ integrins. In normal adult keratinocytes the $\alpha_{5} \beta_{1}$ fibronectin receptor is poorly expressed and diffusely distributed on the basal keratinocyte plasma membrane and is not organized in defined adhesive structures. In contrast, psoriatic keratinocytes show a clear fibronectin receptor staining in vivo, and organize $\alpha_{5} \beta_{1}$ in typical focal contacts in vitro without any obvious increase of its expression and synthesis. These multiple alterations of integrins are also present in uninvolved keratinocytes from psoriatic patients, suggesting a key role for altered integrin-mediated adhesion in the pathogenesis of this disease. (J. Clin. Invest. 1992. 89:1783-1795.) Key words: epidermis • psoriasis • adhesion • polarity $\bullet$ proliferation
\end{abstract}

\section{Introduction}

The contact of epithelial cells with the underlying basal lamina and their reciprocal cell-cell interactions are essential for the assembly, maintenance, and correct function of the epidermis (1). Several classes of molecules (for review see reference 2) are involved in cell-cell and cell-matrix interaction and play a major role in the regulation of epithelial cell proliferation, motility, and differentiation. Among these molecules, a super-family of transmembrane heterodimer surface receptors named integrins (for review see references 3-8) have been recently as-

Address correspondence to Dr. Michele De Luca, Laboratorio di Differenziamento Cellulare, IST, Istituto Nazionale per la Ricerca sul Cancro, Viale Benedetto XV, 10, 16132, Genova, Italy. 1992.

Received for publication 9 July 1991 and in revised form 14 January

J. Clin. Invest.

(c) The American Society for Clinical Investigation, Inc.

$0021-9738 / 92 / 06 / 1783 / 13 \quad \$ 2.00$

Volume 89, June 1992, 1783-1795 sociated to the assembly of epithelial (9) and endothelial cells (10). Integrins are then associated not only with the recognition of extracellular matrix components but also with the genesis of cell-cell interactions (for a recent review see reference 7).

Recently, our laboratories have reported that integrins may play a role in defining adhesion-dependent polarity of human keratinocytes $(9,11,12)$. We found that keratinocytes in vivo and in vitro express the heterodimers $\alpha_{2} \beta_{1}, \alpha_{3} \beta_{1}$, and $\alpha_{6} \beta_{4}$ and that these integrins are sorted, in the presence of the $\mathrm{Ca}^{2+}$ concentration required for optimal epidermal maturation, to discrete keratinocyte membrane domains (9). In particular, $\alpha_{6} \beta_{4}$ is strictly located to the basal aspect of the germinative cell (11, 13) and is found here in hemidesmosomes (14-16), suggesting its role as a basal lamina receptor (11-16). The $\alpha_{2} \beta_{1}$ and $\alpha_{3} \beta_{1}$ integrins are concentrated to the lateral surface of basal and immediately suprabasal keratinocytes, suggesting their potential role in cell-cell adhesion of epithelial cells $(9,11-13,16-$ 18). Very recently, it has been reported that integrin polarization to discrete keratinocyte plasma membrane domains is not yet established in fetal skin and is lost in virally transformed keratinocytes (13).

When human epidermal keratinocytes are cultured in primary or secondary culture, on a feeder layer of lethally irradiated fibroblasts (19), at physiological $\mathrm{Ca}^{2+}$ concentration, and in conditions that allow the reconstitution of a normal epithelium $(20,21)$ suitable for grafting onto patients $(22-25)$, no focal contacts containing $\beta_{1}$ or $\beta_{4}$ integrins are observed in immunofluorescence (9). The adhesion of the reconstituted epidermis is mainly mediated by the $\alpha_{6} \beta_{4}$ integrin, which is organized in typical polymorphous patches in microfilamentfree areas (9), and seems to be part of a "stable anchoring contact" (15).

Psoriasis is a hyperproliferative cutaneous disease of unknown etiology and etiopathogenesis, affecting $\sim 3 \%$ of the population in industrialized countries. Psoriasis is characterized by an abnormal pattern of keratinocyte growth and differentiation and by invasion of an inflammatory infiltrate into both the dermis and the epidermis (26). The alteration of keratinocyte adhesive properties, typical of psoriatic keratinocytes (27), has been proposed as the initial disturbance leading to poorly controlled cell proliferation (28).

In this paper we report that: $(a)$ the integrin heterodimers $\alpha_{2} \beta_{1}, \alpha_{3} \beta_{1}$, and $\alpha_{6} \beta_{4}$ have lost their polarized distribution on the plasma membrane of psoriatic keratinocytes, both in vivo and in vitro; $(b)$ the role of such integrins in mediating keratinocyte adhesion in vitro is modified; $(c)$ the integrin-cytoskeleton relationship is altered, since psoriatic keratinocytes adhere, in vitro, also through focal contacts containing both $\beta_{1}$ and $\beta_{4}$ integrins; $(d)$ psoriatic keratinocytes show a clear fibronectin receptor staining in vivo, and organize $\alpha_{5} \beta_{1}$ in typical focal 
contacts in vitro without any obvious increase of its expression and synthesis.

These alterations of expression, distribution, and function of integrins are also present in keratinocytes from uninvolved skin areas of psoriatic patients. This indicates that integrin alterations are part of a systemic pattern of changes involving the whole integument of psoriatic patients and suggest a central role for adhesion receptors in the pathogenesis of the disease.

\section{Methods}

Cell culture. Human epidermal keratinocytes were obtained from skin biopsies of five healthy adult volunteers and from involved and uninvolved skin of nine patients suffering from psoriasis vulgaris. Uninvolved skin biopsies were taken either close to the lesion $(1-3 \mathrm{~cm}$ from the involved areas) or from very distant, apparently healthy areas. In three out of nine patients, we obtained two to three biopsies from the uninvolved areas. Informed consent was obtained from all patients. Patients were not receiving systemic or topical treatments when biopsies were taken. Cells were cultivated on a feeder layer of lethally irradiated 3T3-J2 cells (a gift from Prof. Howard Green, Harvard Medical School, Boston, MA) as previously described (19-21). In brief, skin biopsies were minced and trypsinized ( $0.05 \%$ trypsin $/ 0.01 \%$ EDTA) at $37^{\circ} \mathrm{C}$ for $3 \mathrm{~h}$. Cells were collected every $30 \mathrm{~min}$, plated $\left(2.5 \times 10^{4} / \mathrm{cm}^{2}\right)$ on lethally irradiated $3 \mathrm{~T} 3-\mathrm{J} 2$ cells $\left(2.4 \times 10^{4} / \mathrm{cm}^{2}\right)$, and cultured in $5 \%$ $\mathrm{CO}_{2}$ and humidified atmosphere in keratinocyte growth medium: DMEM and Ham's F12 media (3:1 mixture) containing FCS (10\%), insulin $(5 \mu \mathrm{g} / \mathrm{ml})$, transferrin $(5 \mu \mathrm{g} / \mathrm{ml})$, adenine $(0.18 \mathrm{mM})$, hydrocortisone $(0.4 \mu \mathrm{g} / \mathrm{ml})$, cholera toxin $(0.1 \mathrm{nM})$, triiodothyronine (20 pM), epidermal growth factor $(10 \mathrm{ng} / \mathrm{ml})$ (a gift from Dr. Carlos George Nascimento, Chiron Corp., Emeryville, CA), glutamine (4 mM), penicillin-streptomycin $(50 \mathrm{IU} / \mathrm{ml})$. Subconfluent primary cultures were trypsinized as above and cells were plated in secondary cultures at a density of $5 \times 10^{3}$ cells $/ \mathrm{cm}^{2}$. Confluent secondary cultures were detached from the surface vessel by incubation in DMEM containing 2.5 $\mathrm{mg} / \mathrm{ml}$ of Dispase II (Boehringer Mannheim Corp., Indianapolis, IN) for $1 \mathrm{~h}$ at $37^{\circ} \mathrm{C}$, and the reconstituted epidermis was fixed in SUSA for $20 \mathrm{~min}$ and stained in hematoxylin/eosin as previously described (21).

Antibodies. The murine monoclonal antibodies DH-12 to $\alpha_{2}, \mathrm{~S} 3-$ 41 and AA3 to $\alpha_{6} \beta_{4}$, and the rabbit polyclonal antiserum 5710 to $\alpha_{6} \beta_{4}$ were generously provided by V. Quaranta, Scripps Research Institute, La Jolla, CA (29). Other mAbs, with the investigators that kindly provided them, are as follows: A1A5, to $\beta_{1}$ : M. Hemler, Dana Farber Cancer Institute, Boston, MA; MAR4, to $\beta_{1}$ : S. Ménard, Istituto Nazionale Tumori, Milano, Italy; J143, to $\alpha_{3}$ : L. Old, Sloan Kettering Institute, New York; F1, to $\alpha_{3}$ : L. Zardi, Istituto Nazionale per la Ricerca sul Cancro, Genova, Italy; G0H3, to $\alpha_{6}$ : A. Sonnenberg, Central Laboratory of the Netherlands Red Cross; MAR6, to $\alpha_{6}$ : S. Ménard, Istituto Nazionale Tumori, Milano, Italy; BIIG2, to $\alpha_{5}$ and AIIB2 to $\beta_{1}$ from C. Damsky, University of California, San Francisco. Rabbit antisera to the fibronectin receptor and to the $\mathrm{COOH}$-terminal synthetic peptide of $\alpha_{5}$ was kindly provided by E. Ruoslahti, La Jolla Cancer Research Foundation, La Jolla, CA. Goat antiserum to $\beta_{1}$ has been described (9). Monoclonal antibodies to $\alpha_{5}$ (SAM 1) and to $\alpha_{2}$ (Gi9) were purchased from Immunotech, Marseille, France. A rabbit antiserum to the $\mathrm{COOH}$-terminal 20 amino acid residues of the cytoplasmic domain of $\beta_{4}$ (SP90395) was produced in our laboratory.

Cytoskeletal proteins associated to focal contacts were studied with mAbs to chicken or human vinculin obtained from Sigma Immunochemicals/Bio Makor, Rehovot, Israel (clones VIN 11-5 and hVIN-1, respectively) and an $\mathrm{mAb}$ cross-reacting with human talin (clone 8d4) donated by K. Burridge, University of North Carolina at Chapel Hill, Chapel Hill, NC.

Immunoprecipitation. Immunoprecipitations were carried out as previously described $(11,29)$. Briefly, growing keratinocyte colonies from normal and psoriatic skin were incubated for $15-20 \mathrm{~h}$ in methionine- and cysteine-free culture media in the presence of $100 \mu \mathrm{Ci} / \mathrm{ml}$ of $\left[{ }^{35} \mathrm{~S}\right]$ methionine and $100 \mu \mathrm{Ci} / \mathrm{ml}$ of $\left[{ }^{35} \mathrm{~S}\right]$ cysteine (Amersham Corp., Arlington Heights, IL). After labeling, cells were detached with $10 \mathrm{mM}$ EDTA, $0.02 \% \mathrm{KCl}$ in PBS, pH 7.4, washed twice in PBS containing 1 $\mathrm{mM} \mathrm{CaCl}{ }_{2}$ and $1 \mathrm{mM} \mathrm{MgCl}_{2}$, and lysed for $30 \mathrm{~min}$ on ice in lysis buffer ( $50 \mathrm{mM}$ Tris- $\mathrm{HCl}, 150 \mathrm{mM} \mathrm{NaCl}, 1 \%$ deoxycholate, $1 \%$ Triton X-100, $0.1 \%$ SDS, $0.2 \%$ sodium azide) $\mathrm{pH} 8.5$ containing $4 \mathrm{mM}$ PMSF, 0.0002 $\mathrm{TIU} / \mathrm{ml}$ aprotinin, and $0.01 \mu \mathrm{g} / \mathrm{ml}$ leupeptin. Lysates were then centrifuged and cleared by the addition of one-tenth the volume of Pansorbin (Calbiochem Corp., La Jolla, CA). Immunoprecipitations were carried out by overnight incubations of the immunoadsorbents (antibodies adsorbed onto Protein-A Sepharose, Pharmacia, Uppsala, Sweden) with aliquots of cell lysates, followed by extensive washing, elution by boiling in Laemmli sample buffer, and reduction with $10 \mathrm{mM}$ dithiothreitol. The procedure was strictly performed at $4^{\circ} \mathrm{C}$. Samples were then analyzed by SDS-PAGE on $6 \%$ polyacrylamide slab gels, followed by autoradiography on Hyperfilm $\beta$-max (Amersham).

RNA blotting. Total cellular RNA was isolated by lysing confluent keratinocytes in secondary culture with the thiocynate phenolchloroform procedure (30). $15 \mu \mathrm{g}$ of denatured RNA was loaded on a $1 \%$ agarose gel containing formaldehyde and transferred onto nylon membrane (OptiBLOT; International Biotechnologies Inc., New Haven, CT) and cross-linked by ultraviolet light. Nylon filters were hybridized overnight at $57^{\circ} \mathrm{C}$ with $1 \times 10^{6} \mathrm{cpm}$ of ${ }^{32} \mathrm{P}$-labeled $\alpha_{5}$ human cDNA probe/ml in $100 \mathrm{mM} \mathrm{NaCl}, 50 \mathrm{mM} 1,4$ piperazinediethansulfonic acid, pH 6.8, 5\% SDS, 1 mM EDTA, 20 mM phosphate buffer, pH 6.8, and $100 \mu \mathrm{g} / \mathrm{ml}$ of yeast total RNA. Filters were washed at high stringency in standard conditions. The hybridization conditions described above were found to give optimal results with our integrin probes.

Immunocytochemistry. Keratinocytes from confluent primary cultures $\left(1 \times 10^{4} \mathrm{cells} / \mathrm{cm}^{2}\right)$ were plated onto 24-well plates (Costar Corp., Cambridge, MA) containing 1.4-cm ${ }^{2}$ round glass cover slips previously coated with feeder layer and cultured as described above. When keratinocyte colonies were evident in phase contrast microscopy (3-5 d after plating) colonies were treated for immunofluorescence. Cover slip-attached keratinocyte colonies obtained from involved and uninvolved skin of psoriatic patients, were fixed in 3\% formaldehyde (from paraformaldehyde) in PBS pH 7.6 containing 2\% sucrose for 5-15 min at room temperature. After rinsing in PBS, cells were permeabilized by soaking cover slips for $3-5$ min at $0^{\circ} \mathrm{C}$ in Hepes-Triton X-100 buffer (20 mM Hepes, pH 7.4, $300 \mathrm{mM}$ sucrose, $50 \mathrm{mM} \mathrm{NaCl}, 3 \mathrm{mM} \mathrm{MgCl}$ and $0.5 \%$ Triton $\mathrm{X}-100$ ).

Indirect immunofluorescence on cell cultures was performed as previously reported $(9,11)$. Briefly, the primary antibody $(10-30 \mu \mathrm{g} / \mathrm{ml})$ was layered on fixed and permeabilized cells and incubated in a humid chamber for $30 \mathrm{~min}$. After rinsing in PBS- $0.2 \%$ BSA, cover slips or tissue sections were incubated in the appropriate rhodamine-tagged secondary antibody (Dakopatts, Copenhagen, Denmark) for $\mathbf{3 0 ~ m i n ~ a t ~}$ $37^{\circ} \mathrm{C}$ in the presence of $2 \mu \mathrm{g} / \mathrm{ml}$ of fluorescein-labeled phalloidin (Sigma Chemical Co., St. Louis, MO). Cover slips were mounted in Mowiol (Hoechst AG, Frankfurt/Main, FRG) and observed in a Zeiss Axiophot photomicroscope equipped with epifluorescence lamp and usually with planapochromatic oil immersion lenses. Fluorescence images were recorded on Kodak T-Max 400 films exposed at 1000 ISO and developed in T-Max Developer for $10 \mathrm{~min}$. at $20^{\circ} \mathrm{C}$.

For immunoperoxidase staining punch biopsies from involved and uninvolved skin were snap frozen in liquid nitrogen and sectioned (4-6 $\mu \mathrm{m})$ in a cryostat; sections were air dried and fixed in a mixture of chloroform and acetone $(1: 1, \mathrm{vol} / \mathrm{vol})$ at $+4^{\circ} \mathrm{C}$ for $10 \mathrm{~min}$. Then, small skin samples were mounted in OCT 4583 embedding compound (Miles Scientific Div., Miles Laboratories Inc., Naperville, IL) and frozen directly in a $-70^{\circ} \mathrm{C}$ refrigerator. Frozen serial sections were cut at 6 $\mu \mathrm{m}$ in a Leitz cryomicrotome, transferred onto microscope slides coated with poly-L-lysine (Sigma Chemical Co.), air dried, and stored at room temperature overnight. The samples were then fixed for $10 \mathrm{~min}$ in a chloroform-acetone mixture (1:1), air dried, and incubated for 10 min in PBS supplemented with $1 \%$ serum of the same species as the secondary antibody. Serial sections were overlaid with $50 \mu \mathrm{l}$ of different antibodies at a concentration of $10-40 \mu \mathrm{g} / \mathrm{ml}$ in HBSS and incubated at 
room temperature for $30 \mathrm{~min}$ in a moist chamber. After a thorough wash in PBS, the sections were incubated with the appropriate biotinylated secondary antibodies and processed for the ABC method (avidinbiotin peroxidase complex) using the Vectastain ABC Kit (Vector Laboratories Inc., Burlingame, CA). After several washes, $100 \mu$ l of substrate was added for 5-10 min, prepared as follows: $5 \mathrm{mg} 3$ amino-9 ethylcarbazole (Sigma Chemical Co.) was dissolved in $1 \mathrm{ml} N, N$-dimethylformamide (E. Merck, Darmstad, FRG) supplemented with $9 \mathrm{ml} 100 \mathrm{mM}$ sodium acetate pH 5.2 and $100 \mu$ l of $12 \% \mathrm{H}_{2} \mathrm{O}_{2}$. All samples were counterstained with Mayer's haemalum solution, mounted in Kaiser's glycerol gelatin (Merck), and examined with a Zeiss Axiophot photomicroscope equipped with planapochromatic lenses. Pictures were taken with Kodak Ektachrome 100 reversal film.

Adhesion assays. Adhesion assays were performed as described (11). Briefly, 96-well plates were coated for $1 \mathrm{~h}$ at $37^{\circ} \mathrm{C}$ with mouse laminin $(10 \mu \mathrm{g} / \mathrm{ml})$ or matrigel $(2 \mu \mathrm{g} / \mathrm{ml})$ (a gift from A. Albini, Istituto Nazionale per la Ricerca sul Cancro, Genova). Keratinocytes from confluent secondary cultures were plated $\left(3-6 \times 10^{4}\right.$ cells/well) in keratinocyte growth medium without serum. For inhibition assays, rabbit antiserum 5710 to $\alpha_{6} \beta_{4}$, goat antiserum to $\beta_{1}$ (1:50 or 1:100 dilutions), control normal sera, or unrelated antibodies were added at plating. After $12 \mathrm{~h}$ at $37^{\circ} \mathrm{C}$ with sera, cells were washed, fixed in $3 \%$ formaldehyde, $2 \%$ sucrose PBS for 5 min, stained with $0.5 \%$ crystal violet, $20 \%$ methanol for $15 \mathrm{~min}$, washed and dried. The dye was eluted with $50 \%$ ethanol, 0.1 M Na citrate, $\mathrm{pH}$ 4.2. Optical density was read in a Titertek Multiscan at $540 \mathrm{~nm}$ (Flow Laboratories, Irvine, Scotland). Experiments were performed three times in triplicate for each cell strain.

\section{Results}

Cell culture. Keratinocytes obtained from involved and uninvolved skin biopsies (see Methods) of nine different psoriatic patients have been cultured as described in Methods. The shape and growth behavior of keratinocytes and keratinocyte colonies cultured from psoriatic skin and from healthy donors of comparable age were not significantly different except for a higher number of abortive colonies in psoriatic cultures (not shown). Cells obtained from psoriatic lesions were able to reconstitute a stratified squamous epithelium in vitro. However, when compared with cultures of normal keratinocytes (Fig. 1, inset), the epidermis reconstituted from a psoriatic lesion (Fig. 1) showed a remarkable increase in the number of squames as well as in the release of squames in the culture medium (asterisks). In several sections obtained from different psoriatic epithelial sheets, a basal layer enriched in smaller and less organized basal cells (compared to normal epithelial sheets, Fig. 1, inset) was consistently observed (Fig. 1, arrowheads).

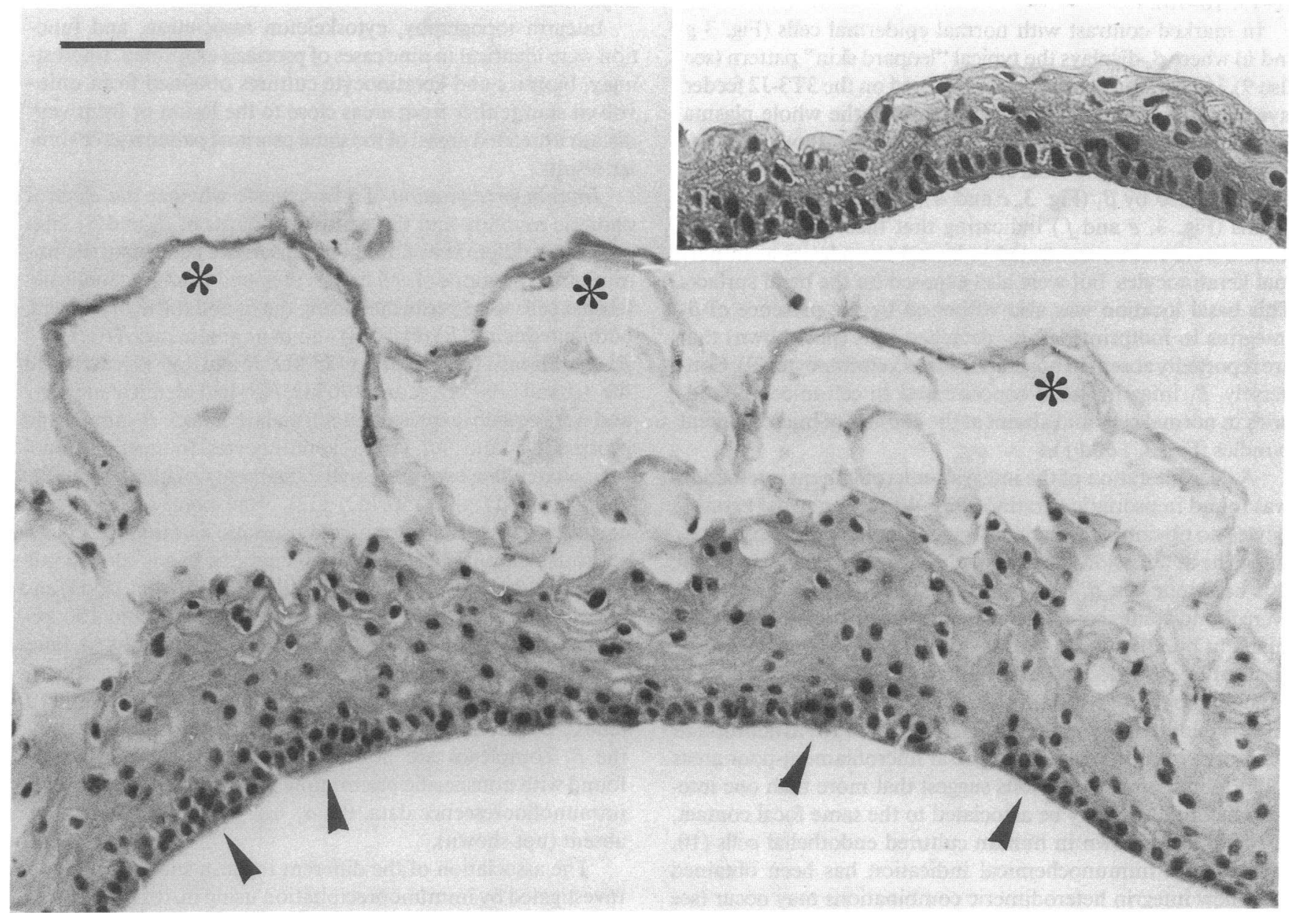

Figure 1. Culture of human keratinocytes. Keratinocytes were obtained from skin biopsies of nine psoriatic patients and five healthy volunteers and cultured on lethally irradiated 3T3-J2 cells as described in Methods. The reconstituted epidermis was detached from the surface vessel by incubation in Dispase (see Methods) and stained in hematoxylin/eosin. Asterisks indicate squames detaching from the in vitro reconstituted epidermis. Arrowheads indicate the increased amount of poorly organized basal keratinocytes. (Inset) A sheet of epidermis reconstituted in vitro from keratinocytes obtained from a healthy donor is shown for comparison. Bar, $80 \mu \mathrm{m}$. 
Integrin topography, cytoskeleton association and function in normal and psoriatic keratinocytes. Skin biopsy sections and keratinocytes cultured from psoriatic lesions displayed loss of integrin polarized topography and alteration of integrin-cytoskeleton association.

In psoriatic skin sections the $\beta_{4}$ subunit was distributed on the basal and lateral surface of basal keratinocytes and also around the immediate suprabasal cells (Fig. $2 a$ ); this pattern was clearly different from that of normal skin (Fig. $2 \mathrm{~g}$ ) where $\beta_{4}$ was sharply delimited to the basal domain of basal cells. In uninvolved skin areas of psoriatic patients (biopsies taken either from areas close to the lesion or from very distant unrelated areas, see Methods), $\beta_{4}$ was also found all around basal and suprabasal cells (Fig. $2 c$ ). $\beta_{1}$ mAbs stained involved (Fig. 2 $b$ ) and uninvolved (Fig. $2 d$ ) skin all around the boundaries of basal and suprabasal cells while, in normal epidermis (Fig. $2 h$ ), $\beta_{1}$ integrins were concentrated at the cell-cell contact. Immunostaining with mAbs to $\alpha_{6}$ gave an identical pattern to $\beta_{4}$ while $\alpha_{2}$ and $\alpha_{3}$ were located exactly as $\beta_{1}$ (not shown). In conclusion, the overall integrin pattern of psoriatic epidermis was similar in involved and noninvolved skin areas, slight differences being related to the different histological patterns. In any case, this integrin distribution was markedly different from that described in normal epidermis by ours and other groups (e.g., 9, 11-13, 16-18).

In marked contrast with normal epidermal cells (Fig. $3 \mathrm{~g}$ and $h$ ) where $\beta_{4}$ displays the typical "leopard skin" pattern (see also 9), in psoriatic keratinocytes cultured on the 3T3-J2 feeder layer, $\beta_{4}$ (Fig. 3, $a$ and $b$ ) was exposed on the whole plasma membrane, including cell-cell boundaries, without any defined restriction to the basal surface. A similar topography was displayed also by $\beta_{1}$ (Fig. 3, $c$ and $d$ ), $\alpha_{2}$ (not shown), and $\alpha_{3}$ chains (Fig. 3, $e$ and $f$ ) indicating that these two $\beta_{1}$ heterodimers were not concentrated to lateral boundaries as in normal keratinocytes, but were also exposed on the basal surface. This basal location was also witnessed by the presence of $\beta_{1}$ integrins in footprints left by detached cells (not shown) that are reportedly absent in normal cultured keratinocytes (9). Conversely, $\beta_{1}$ integrins were concentrated to cell-to-cell boundaries in normal cells and absent at the endings of microfilament bundles (Fig. 3, $i$ and $j$ ).

A deep alteration of the integrin-microfilament interaction was found in psoriatic keratinocytes. While in normal keratinocytes no obvious association of microfilament bundles and $\beta_{1}$ integrins at adhesion plaques could be described (9), in psoriatic keratinocytes, $\beta_{1}$ (Fig. 4, $c$ and $d$ ) and $\alpha_{3}$ (Fig. 4, $e$ and $f$ ) were found at sites coincident with the termini of F-actin microfilament bundles which turned out to be focal contacts on the basis of interference reflection microscopy and their talin and vinculin content (not shown). Even more surprisingly, $\beta_{4}$ was in part relocated to focal contacts (Fig. $4, a$ and $b$ ) in addition to its more typical topography at basal microfilament-poor areas (9). Preliminary observations suggest that more than one integrin heterodimer may be associated to the same focal contact, as previously shown in human cultured endothelial cells (10, 31 ), but no immunochemical indication has been obtained that new integrin heterodimeric combinations may occur (see next paragraph).

A side observation made on psoriatic keratinocyte colonies was that the relative number of focal contacts was increased underneath cells and that focal contacts were not found predominantly at the periphery of individual colonies as described in normal keratinocytes (9). Indeed, talin-(Fig. 5, $a$ and $c$ ) and vinculin-positive spots (not shown) were very numerous all over the attachment surface and were not preferentially located at the margins of migrating basal cells as in normal keratinocyte colonies (Fig. 5, $b$ and $d$ ). These spots corresponded to focal contacts on the basis of interference reflection microscopy (not shown) and indicated that psoriatic keratinocytes, along with alterations of integrin distribution, also displayed changes of their cytoskeleton and adhesion systems as compared to normal keratinocytes.

The issue that the keratinocyte adhesion machinery is changed in psoriasis is also supported by experiments aimed at studying the role of the $\beta_{1}$ and $\beta_{4}$ complexes in psoriatic keratinocytes adhesion to laminin or matrigel in vitro. As previously described $(11,13)$, in normal keratinocytes, the antiserum against the $\alpha_{6} \beta_{4}$ heterodimer was able to inhibit keratinocyte adhesion (Fig. $6 A$ ) but the antiserum to $\beta_{1}$ did not significantly affect keratinocyte attachment (Fig. $6 A$ ); rather, the antiserum to $\beta_{1}$ inhibited the normal colony assembly and stratification $(9,13,17)$. In contrast, both the $\alpha_{6} \beta_{4}$ and the $\beta_{1}$ antisera were equally potent in inhibiting psoriatic keratinocyte adhesion to matrigel (Fig. $6 \mathrm{~B}$ ) or laminin (not shown). These results further highlight that the role of $\beta_{1}$ and $\beta_{4}$ integrins in mediating keratinocyte adhesion in vitro are changed in psoriasis.

Integrin topography, cytoskeleton association, and function were identical in nine cases of psoriasis examined. Interestingly, biopsies and keratinocyte cultures obtained from uninvolved skin (either from areas close to the lesion or from very distant unrelated areas) of the same psoriatic patients gave similar results.

Immunoprecipitation. To investigate whether the electrophoretic mobility and the relative amounts of $\beta_{1}$ and $\beta_{4}$ integrins were different in normal and psoriatic keratinocytes, immunoprecipitations of cell lysates prepared from metabolically labeled cells were performed using the $\beta_{1}$ and the $\alpha_{6} \beta_{4}$ antisera, both in reducing $(R)$ (Fig. $7 A$ ) and in nonreducing $(N R)$ (Fig. 7 $B)$ conditions. The $\alpha_{6}$ band $(125 \mathrm{kD}, R$ and $150 \mathrm{kD}, N R)$ and the $\beta_{4}$ band $(200 \mathrm{kD}, R$ and $190 \mathrm{kD}, N R)$ had identical mobility and were equally expressed in normal $(A$, lane $5 ; B$, lane 4$)$ and psoriatic ( $A$, lane $6 ; B$, lane 3$)$ keratinocytes. In these immunoprecipitates the two proteolytic fragments of the $\beta_{4} 200-\mathrm{kD}$ band (180 kD and $150 \mathrm{kD})(32)$, were poorly evident and equally expressed in normal and psoriatic keratinocytes.

Anti- $\beta_{1}$ antibodies immunoprecipitated bands corresponding to $\beta_{1}(130 \mathrm{kD}, R$ and $110 \mathrm{kD}, N R), \beta_{1}$ precursor $(95 \mathrm{kD})$ and other bands corresponding to the $\alpha_{2}(165 \mathrm{kD}, R$ and $160 \mathrm{kD}$, $N R)$ and the $\alpha_{3}(130 \mathrm{kD}, R$ and $150 \mathrm{kD}, N R)$ subunits $(A$, lanes 1 and 2; $B$, lanes 1 and 2). The $\alpha_{2} \beta_{1}$ and $\alpha_{3} \beta_{1}$ mobility was comparable in normal $(A$, lane $1 ; B$, lane 2$)$ and psoriatic $(A$, lane $2 ; B$, lane 1$)$ keratinocytes. The faint bands present above the $\beta_{1}$ complexes are not consistently observed, and often found with nonspecific preimmune sera. In agreement with the immunofluorescence data, the $\alpha_{1}, \alpha_{4}, \beta_{2}$, and $\beta_{3}$ chains were absent (not shown).

The association of the different integrin subunits was then investigated by immunoprecipitation using mAbs against the $\alpha$ chains. As shown in Fig. 8 (panel $A, R$; panel $B, N R$ ), the anti$\alpha_{6} \mathrm{mAb}(\mathrm{G} 0 \mathrm{H} 3)$ immunoprecipitated only the $\alpha_{6} \beta_{4}$ heterodimer ruling out the possibility of an $\alpha_{6} \beta_{1}$ association. The $\beta_{4}$ antiserum raised against a synthetic peptide belonging to the COOH-terminus of $\beta_{4}$ (SP90395) showed that $\beta_{4}$ associated 


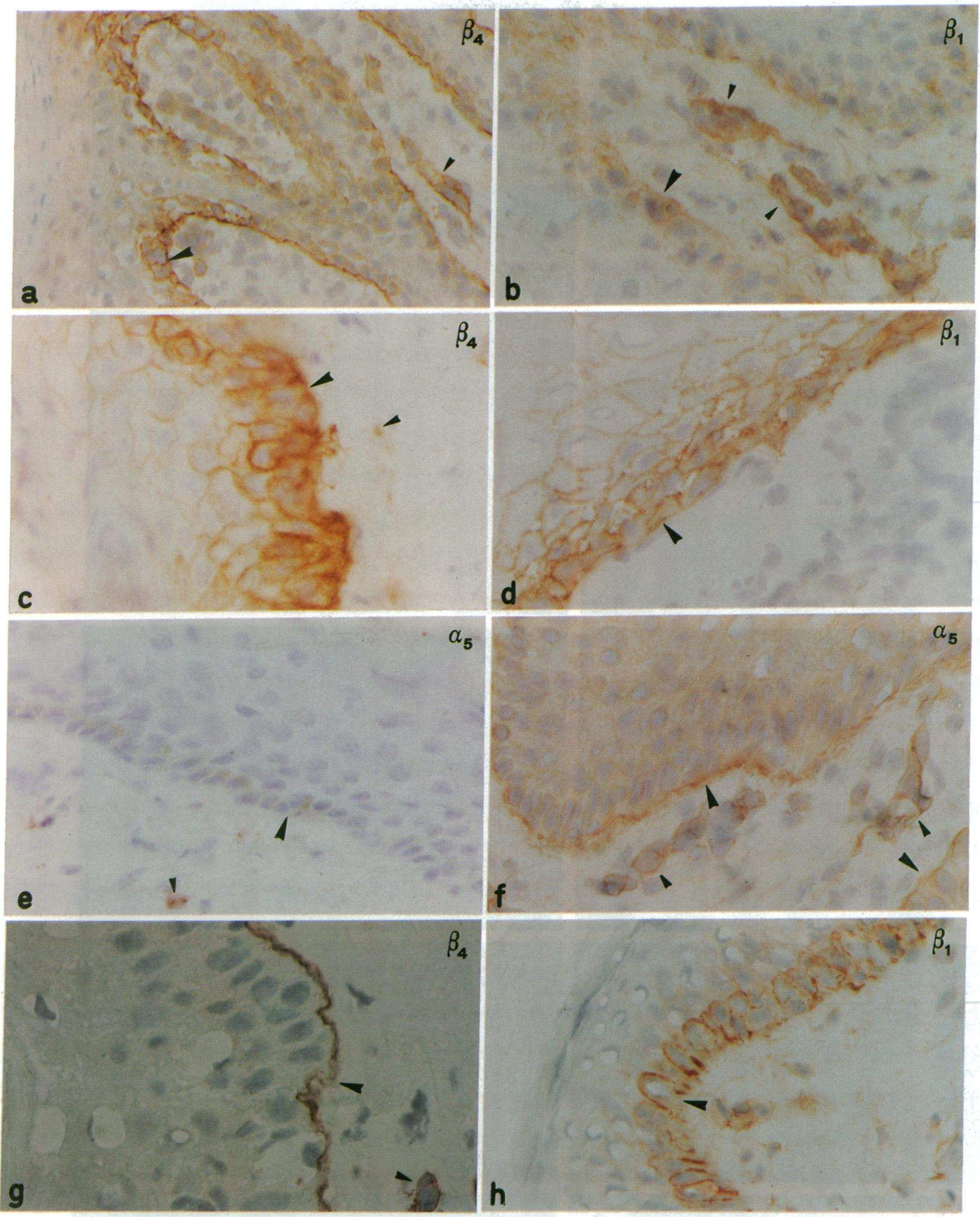

Figure 2. Immunoperoxidase staining of normal and psoriatic skin sections. Localization of $\beta_{4}(a, c$, and $g), \beta_{1}(b, d$, and $h)$, and $\alpha_{5}(e$ and $f)$ in psoriasis-involved $(a, b$, and $f)$, psoriasis-uninvolved $(c$ and $d)$, and normal $(g$ and $h)$ skin sections. The boundary between basal cells and the basement membrane zone $(g)$ of normal skin is sharply immunostained with mAb AA3 to $\beta_{4}$. Sections of involved $(a)$ and uninvolved $(c)$ psoriatic skin show that $\beta_{4}$ is located also to lateral surfaces. In normal skin $(h), \beta_{1}$ is concentrated to the apical and lateral aspects of basal and occasionally suprabasal cells with little or no localization at basal domains. In involved $(b)$ and uninvolved $(d)$ psoriatic skin $\beta_{1}$ integrins were clearly located to the basal domains of basal cells in contact with the basement membrane zone indicating that the normal sorting of integrins was altered. In the skin of normal donors no $\alpha_{5}$ is exposed in epidermal cells $(e)$ while in psoriatic skin $\alpha_{5}$ is notably expressed and mostly located to the basal domain of basal cells $(f)$. Larger arrowheads in all panels indicate the position of the basement membrane zone while smaller arrowheads indicate integrin positive structures in the dermis. Frames $a-f$ were taken with a $\times 63$ lens while frames $g$ and $h$ were taken with a $\times 100$ lens. 

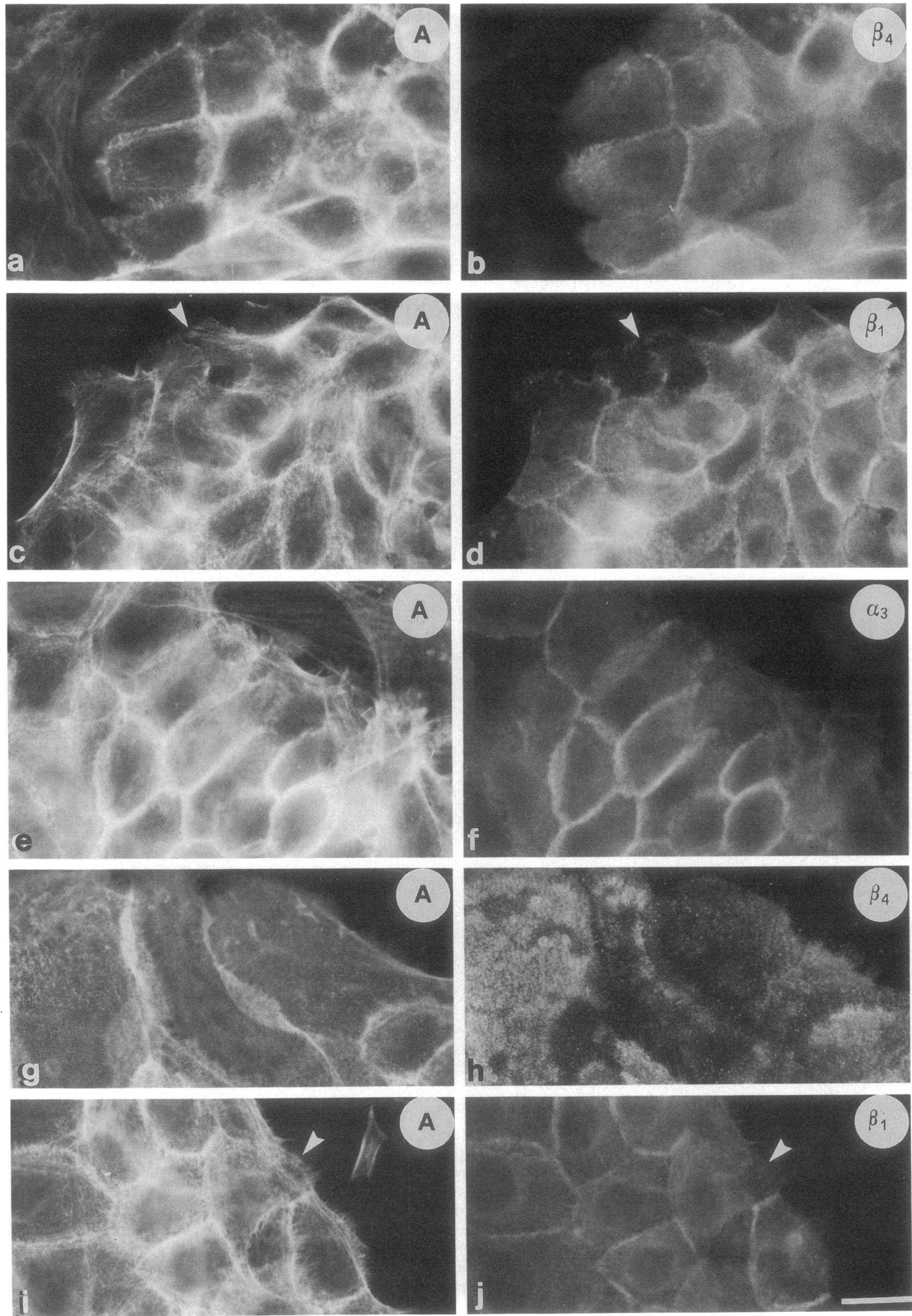

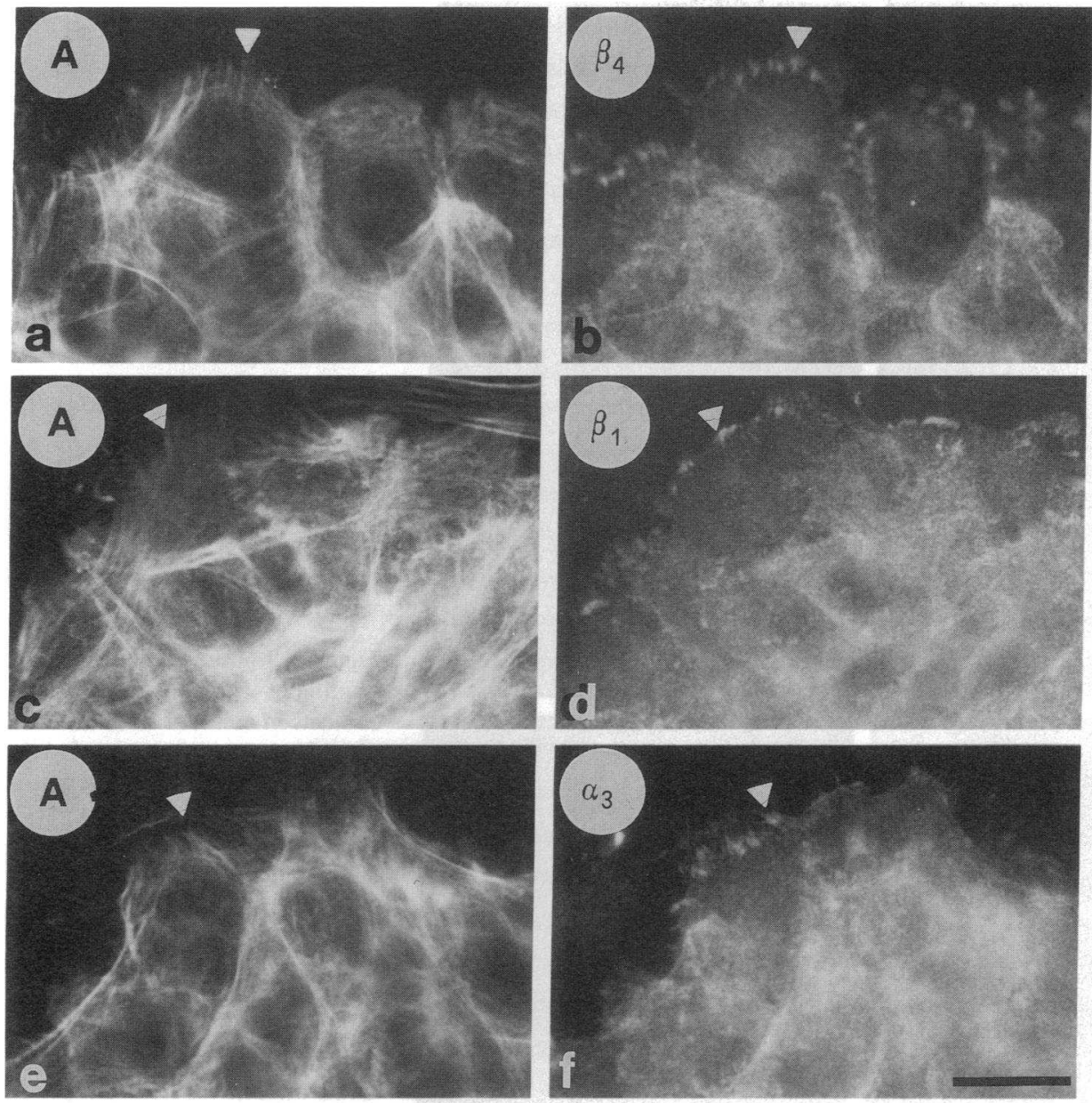

Figure 4. Immunofluorescence staining of cultured keratinocytes from psoriatic skin. Details of the distribution of $\beta_{4}(b)$, $\beta_{1}(d)$, and $\alpha_{3}(f)$ integrins in human keratinocyte colonies obtained from psoriasis patients (see legend to Fig. 3). The corresponding staining for F-actin is shown in $a, c$, and $e$. Triangles show that $\beta_{4}(b), \beta_{1}(d)$, and $\alpha_{3}(f)$ are found in streaks at the endings of microfilament bundles (also indicated by triangles in $a, c$, and $e$ ) at structures corresponding to focal contacts. The central part of individual keratinocyte colonies is bulging up and is then slightly out of focus in all panels; this was done on purpose to highlight the presence of integrins at substratum-contacting focal contacts. Bar, $5 \mu \mathrm{m}$. only with $\alpha_{6}$ (not shown). MAbs against $\alpha_{2}$ (DH-12) and $\alpha_{3}$ (J-143) immunoprecipitated only the $\alpha_{2} \beta_{1}$ and the $\alpha_{3} \beta_{1}$ heterodimers, respectively, both in normal and psoriatic keratinocytes. In summary, the alteration of integrin topography and cytoskeleton interaction of psoriatic keratinocytes was not accompanied by obvious alterations in integrin synthesis and/or subunit association.

Identical results were obtained in immunoprecipitates from keratinocytes cultured from nine different psoriasis and from keratinocytes cultured from uninvolved skin biopsies (not shown).

Expression of the fibronectin receptor $\alpha_{5} \beta_{1}$ in normal and psoriatic keratinocytes. Several authors have reported that the $\alpha_{5} \beta_{1}$ integrin is not expressed by normal human adult epidermis $(15,33-36)$ or poorly expressed in developing human inte- guments (37). In cultured human keratinocytes the expression of the $\alpha_{5} \beta_{1}$ fibronectin receptor is finely regulated by the keratinocyte differentiation stage (38). However, in vitro, this integrin is weakly and diffusely distributed on the keratinocyte plasma membrane (17) and is not organized in defined adhesive structures (9), so that the function of $\alpha_{5} \beta_{1}$ in human keratinocytes is not fully understood. Recently, the clustering of the fibronectin receptor in defined adhesive structures has been correlated with keratinocyte migration during wound healing (39).

A battery of $\alpha_{5}$ mono- and polyclonal antibodies (see Methods) did not stain normal skin biopsies (Fig. $2 e$ ) but gave a clear basal staining in psoriatic skin biopsies (Fig. $2 f$ ). In normal cultured keratinocytes, all $\alpha_{5}$ mono- and polyclonal antibodies did not give any positive immunofluorescence signal, as

Figure 3. Immunofluorescence staining of cultured keratinocytes from normal and psoriatic skin. Distribution of $\beta_{4}(b, h), \beta_{1}(d, j)$, and $\alpha_{3}(f)$ integrins in human keratinocyte colonies obtained from psoriasis patients $(a-f)$ or from clinically normal donors $(g-j)$ and grown on glass cover slips in complete medium. The corresponding staining for $\mathrm{F}$-actin is shown in $a, c, e, g$, and $i$. The cells were immunofluorescently stained with mouse mAbs and co-stained with fluorescein-labeled phalloidin. The patterns of $\beta_{4}(b), \beta_{1}(d)$, and $\alpha_{3}$ staining $(f)$ indicate that these integrins are distributed on both the basal and lateral aspects of the plasma membrane; some immunoreactivity for $\beta_{1}$ integrins occurs at the termini of stress fibers (e.g., at arrowheads in $c$ and $d$; see also Fig. 4). Staining was also found in footprints left by cells which had been mechanically detached during the staining procedures indicating that all integrins were located basally (not shown) and were in contact with the substrate. The distribution of $\beta_{4}$ in normal keratinocytes $(h)$ occurs in patches on the substratum-contacting surface showing the previously described "leopard skin" pattern without any obvious enrichment at intercellular boundaries; $\beta_{1}$ in normal cultured keratinocytes $(j)$ is found at cell-cell contacts without any enrichment at the edges of stress fibers (e.g., at arrowheads in $i$ and $j$ ). Bar, $5 \mu \mathrm{m}$. 

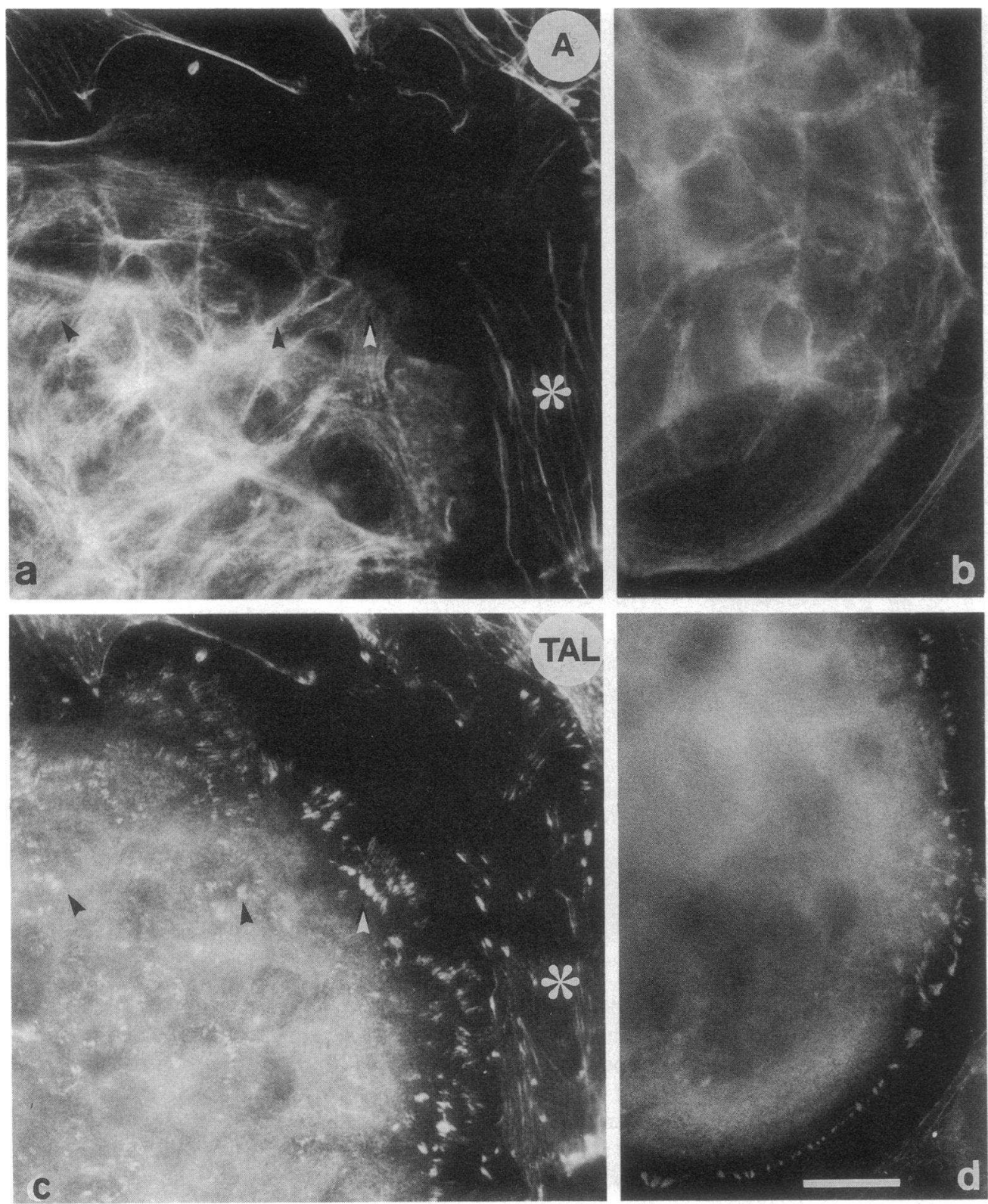

Figure 5. Immunofluorescence staining of talin-containing focal contacts in cultured keratinocytes from normal and psoriatic skin. Topography of talin in a colony of psoriatic keratinocytes (c) co-stained for F-actin (a) versus a colony of normal keratinocytes ( $d$, co-stained for F-actin in $b$ ). A large number of talincontaining streaks are located at the endings of short microfilament bundles (some are indicated by arrowheads) at the substrate-attachment surface of psoriatic keratinocytes $(c)$ and also in mouse fibroblasts of the feeder layer (e.g., at asterisk). The number of talin-containing streaks is comparatively reduced in colonies of cultured normal keratinocytes $(b, d)$ where focal contacts are predominantly located to the free edge of peripheral cells. Bar, $5 \mu \mathrm{m}$. previously reported (9). A polyclonal serum raised to the cytoplasmic domain of $\alpha_{5}$ was used to provide internal control in view of its reactivity with nonhuman cells. This antiserum could indeed detect the fibronectin receptor in the mouse fibroblasts of the feeder layer but no appreciable expression of $\alpha_{5}$ was found in adjacent normal keratinocyte colonies (Fig. 9, $c$ and $d$ ). In keratinocytes cultured from biopsies obtained from involved and uninvolved skin of psoriatic patients, we observed that the $\alpha_{5}$ subunit was abundantly distributed on the whole basal keratinocyte cell surface and also in some intercellular boundaries (Fig. 9, $a$ and $b$ ). On the basal aspect of cells, $\alpha_{5}$ was found along the endings of microfilament bundles (Fig. $9, e$ and $f$ ) together with vinculin and talin (not shown), indicating that, in psoriatic keratinocytes, $\alpha_{5}$ is organized also in focal contacts.

To investigate whether the organization of $\alpha_{5}$ in defined adhesive structures was accompanied by an increased expres- sion of this protein, we analyzed the levels of $\alpha_{5}$ mRNA. Total RNA extracted from normal (Fig. 10, lanes 1 and 2) and psoriatic (Fig. 10, lanes 3-5) keratinocytes was hybridized with the specific human $\alpha_{5}$ cDNA probe. As shown in Fig. 10, the $\alpha_{5}$ 4.1-kb transcript, consistent in size with the $\alpha_{5}$ transcript present in several fibroblastic cell lines (not shown), was present in all keratinocyte strains. No significant difference in the expression of the $\alpha_{5}$ mRNA was observed in different psoriatic compared to normal keratinocytes (except for a slight increase in the PS1 strain; Fig. 10, lane 3). Comparable amounts of RNA were loaded in each lane, as assessed by ethidium bromide staining (not shown) and by cyclophilin hybridization (Fig. 10, arrowhead).

Immunoprecipitations performed with an anti-human $\alpha_{5}$ mAb (SAM-1) showed comparable amount of the $\alpha_{5} \beta_{1}$ heterodimer in psoriatic versus normal keratinocytes (Fig. 8, panel $A$, $R$; panel $B, N R)$. The $\alpha_{5}$ subunit was associated only with the $\beta_{1}$ 


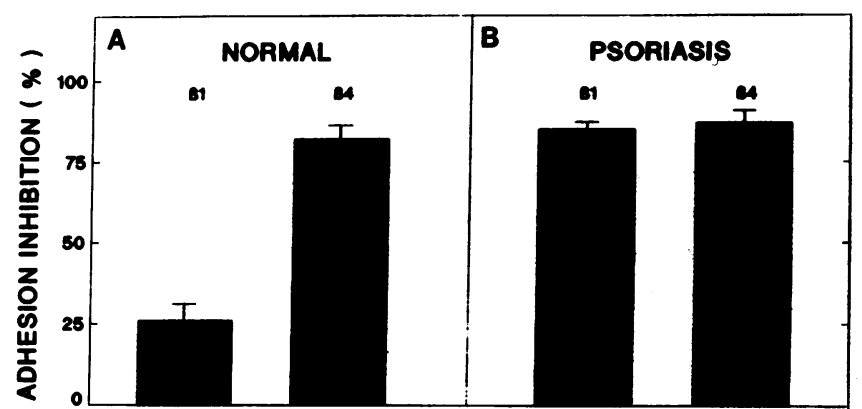

Figure 6. Prevention of keratinocyte adhesion by antisera to integrins. Keratinocytes obtained from confluent secondary cultures were plated on matrigel in the presence of anti- $\beta_{1}$ or anti- $\beta_{4}$ polyclonal sera and processed as described in Methods. Each point was averaged from triplicates of three experiments.

chain both in normal and psoriatic keratinocyte colonies. Identical results were obtained in immunoprecipitates of nine different psoriasis cell strains and from keratinocytes cultured from uninvolved skin biopsies (not shown).

Overall, data obtained by investigating $\alpha_{5}$ suggest that the biological role of the $\alpha_{5} \beta_{1}$ fibronectin receptor on the psoriatic keratinocyte plasma membrane may be due to its clustering at adhesive structures without involving any increased expression or any different protein assembly.

\section{Discussion}

Psoriasis is a common and chronic disease of unknown etiology characterized by an abnormal pattern of keratinocyte growth and differentiation, alteration of the skin capillary net-
A

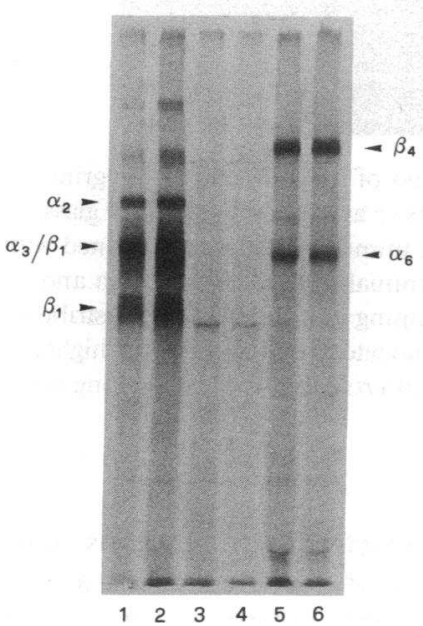

B

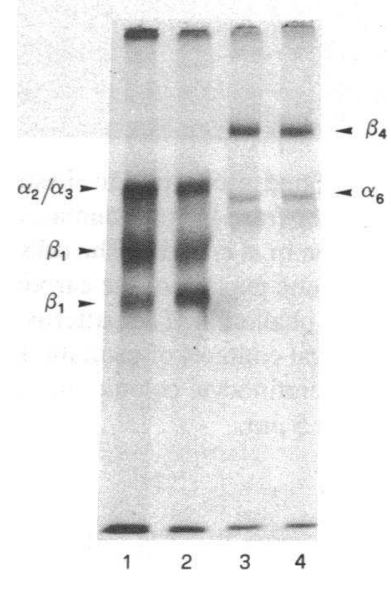

Figure 7. Immunoprecipitations of integrins. Detergent lysates of metabolically radiolabeled growing keratinocyte colonies were immunoprecipitated with $\beta_{1}$ and $\beta_{4}$ antisera as described in Methods. The eluates were analyzed by SDS-PAGE under reducing $(A)$ and nonreducing $(B)$ conditions. $(A)$ Normal keratinocytes: lanes 1 and 5 ; psoriatic keratinocytes: lanes 2 and 6 . Unrelated antibodies in lanes 3 and 4. (B) Normal keratinocytes: lanes 2 and 4; psoriatic keratinocytes: lanes 1 and 3
A

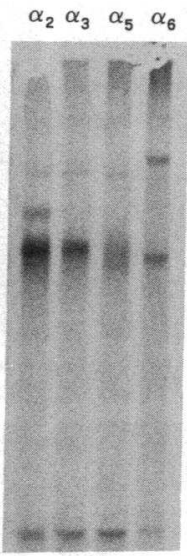

PSORIASIS

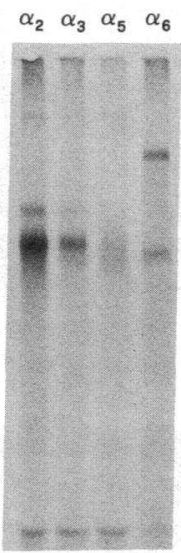

NORMAL

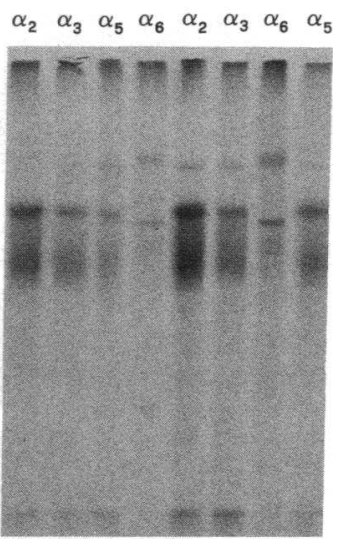

NORMAL PSORIASIS
Figure 8. Immunoprecipitations of integrins. Detergent lysates of metabolically radiolabeled growing keratinocyte colonies, were immunoprecipitated with mAbs to different $\alpha$ subunits as described in Methods. The eluates were analyzed by SDS-PAGE under reducing $\left(R\right.$, panel $A$ ) and nonreducing (NR, panel $B$ ) conditions. The anti- $\alpha_{2}$ mAb immunoprecipitated the $\alpha_{2}(165 \mathrm{kD}$ under $R$ and $160 \mathrm{kD}$ under $N R$ conditions) and $\beta_{1}(130 \mathrm{kD}$ under $R$ and $110 \mathrm{kD}$ under $N R$ conditions) subunits. The anti- $\alpha_{3} \mathrm{mAb}$ immunoprecipitated the $\alpha_{3}(130$ $\mathrm{kD}$ under $R$ and $150 \mathrm{kD}$ under $N R$ conditions) and the $\beta_{1}$ subunits. The anti- $\alpha_{5} \mathrm{mAb}$ immunoprecipitated the $\alpha_{5}(135 \mathrm{kD}$ under $R$ and $155 \mathrm{kD}$ under $N R$ conditions) and the $\beta_{1}$ subunits. The anti- $\alpha_{6} \mathrm{mAb}$ immunoprecipitated the $\alpha_{6}(125 \mathrm{kD}$ under $R$ and $150 \mathrm{kD}$ under $N R$ conditions) and the $\beta_{4}$ subunits ( $200 \mathrm{kD}$ under $R$ and $190 \mathrm{kD}$ under $N R$ conditions).

work, and inflammation of both dermis and epidermis (26, for review see reference 28 ). The complex heredity of the disease suggests that one or more primary and genetically determined defects must be present. The disorder of cell proliferation and differentiation has been recently correlated with an altered expression of several cytokines (some of which are synthesized and secreted by keratinocytes themselves, 40,41 ) which have a key role in the regulation of the keratinocyte function (42). Altered levels of transforming growth factor $\alpha(43-44)$, transforming growth factor $\beta(45)$, interleukin-1 and $6(46,47)$, interferon- $\gamma(48)$, overexpression of the epidermal growth factor/ transforming growth factor $\alpha$ receptor (49) and increased expression of some protooncogenes (50) have been reported. These alterations can be responsible for the autocrine stimulation of epidermal cell proliferation and induce at the same time a cascade of events leading to $T$ cell activation, chemotaxis, and consequent inflammation of the skin (48). However, these alterations are not present in uninvolved skin of psoriatic patients, and it is not clear whether these altered parameters are the consequence or the cause of the disease. One of the most likely hypotheses that has been advanced to explain the increased epidermal cell proliferation, is an initial decreased adhesiveness of keratinocytes, which in turn leads to loss of controlled cell proliferation, alteration of cell signaling, and consequent inflammation $(27,28,51)$.

In this paper we show that the adhesive machinery involving integrin receptors is altered in psoriatic keratinocytes. More important, the integrin disturbance occurs at different levels. 

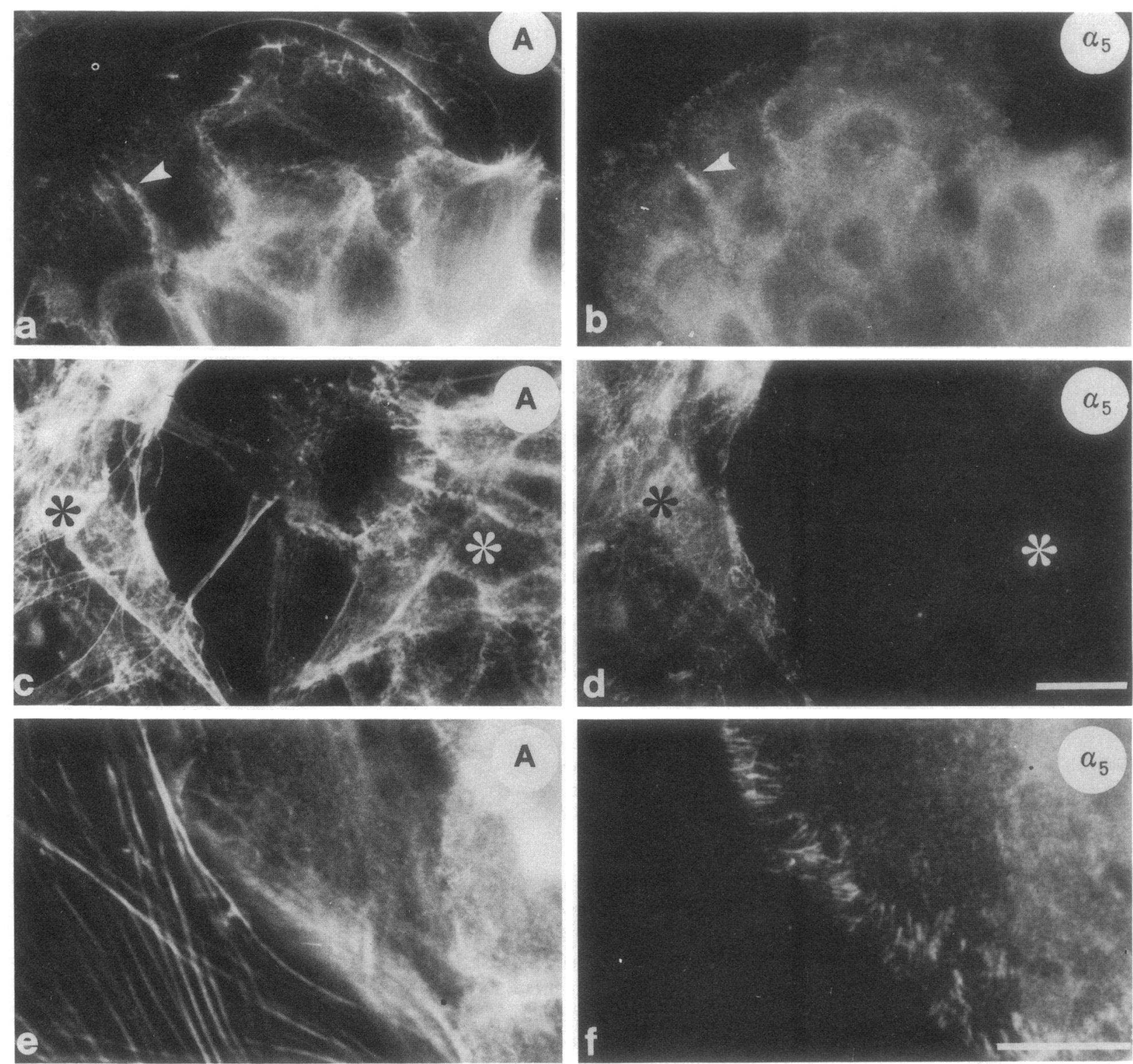

Figure 9. Immunofluorescence staining of cultured keratinocytes from normal and psoriatic skin. Distribution of $\alpha_{5}(b, d$, and $f)$ integrins in human keratinocyte colonies obtained from psoriatic patients $(a, b, e$, and $f)$ or from normal human donors $(c$ and $d)$ and grown on glass cover slips in complete medium. The corresponding staining for F-actin is shown in $a$, $c$, and $e$. The cells were immunofluorescently stained with a mouse mAb (SAM $1, b$ and $f$ ) or with a rabbit serum raised against a synthetic peptide of the carboxy-terminal cytoplasmic domain and cross-reacting among species $(d)$. Cells were co-stained with fluorescein-labeled phalloidin. The patterns of staining indicate that $\alpha_{5}$ is distributed on both the basal and lateral aspects of the plasma membrane as well as in focal contacts of psoriatic keratinocyte colonies (see $f$, for higher magnification). The integrin $\alpha_{5}$ is hardly found or absent in normal human keratinocyte colonies ( $d$, white asterisk) but is located along stress fibers in mouse fibroblasts belonging to the feeder layer $(d$, black asterisk). Bar, $5 \mu \mathrm{m}$.

The first major change consisted in altered topography of integrins. In normal keratinocytes, the $\alpha_{6} \beta_{4}$ heterodimer is located only to the face of basal keratinocytes contacting the basement membrane zone $(9,11,13,16)$, whereas $\alpha_{2} \beta_{1}$ and $\alpha_{3} \beta_{1}$ integrins are concentrated to the lateral surfaces of basal and immediately suprabasal cells $(9,11,13,16-18)$. Such a sorting of different integrins suggests the existence of an adhesion-dependent polarity $(9,13)$. In contrast, psoriatic keratinocytes lose the sorting of integrins to discrete domains of the plasma membrane. This loss of polarization is a general feature of all integrin heterodimers. We do not know whether this lack of polar- ization is limited only to the correct sorting of integrins on the keratinocyte cell membrane, or whether this reflects a more complex disturbance of keratinocyte polarity involving other cell adhesion molecules. It is interesting to note, however, that integrin polarization to discrete keratinocyte plasma membrane domains is not yet established in fetal skin and is lost in virally transformed keratinocytes (13), both conditions implying accelerated cell proliferation. As shown by immunoprecipitations, no new heterodimers appear that are not expressed in normal keratinocytes. In particular, $\alpha_{6}$ associates only with $\beta_{4}$, and $\beta_{4}$ does not form complexes with other $\alpha$ subunits. 


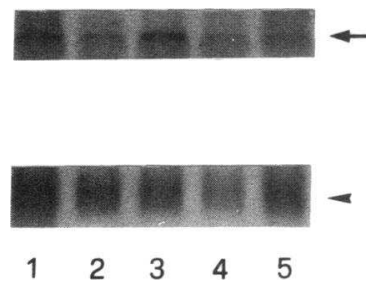

$-4.1 \mathrm{~Kb} \quad$ Figure 10. Northern blot analysis. $15 \mu \mathrm{g}$ of total RNA extracted from keratinocytes cultured from healthy donors (lanes 1 and 2) and psoriatic patients (lanes 3-5) were hybridized with the specific $\alpha_{5}$ cDNA probe as de-

scribed in Methods. Comparable amounts of RNA were loaded in each lane as assessed by ethidium bromide staining and hybridization with a specific cyclophilin cDNA probe (arrowhead).

The second alteration concerns the integrin-cytoskeleton association. Since $\alpha_{6} \beta_{4}$ is localized to hemidesmosomes (1416 ), it is not surprising that normal keratinocytes in vitro lack adhesion plaques containing $\beta_{1}$ or $\beta_{4}$ integrins. In fact, $\alpha_{6} \beta_{4}$ is organized in typical patches in microfilament-free areas. In contrast, psoriatic keratinocytes show typical focal contacts containing both $\beta_{1}$ and $\beta_{4}$ integrins. This indicates the novel fact that almost any integrin may be found at adhesion plaques at the endings of microfilament bundles and thus integrin association with the cytoskeleton may be regulated in different ways in different cellular systems. Thus, under defined circumstances, $\alpha_{6} \beta_{4}$ may lose its association with hemidesmosomes $(14,16)$ and, as well as any known integrin $(10,31,52)$, may become part of the membrane-microfilament interaction complex. It is a matter for future investigations whether in psoriasis both the lack of integrin polarization and the altered cytoskeleton association are due to an intrinsic and primary defect of the epidermal cell itself, or are somehow driven by modification of the basal lamina or other extracellular matrix components of the psoriatic skin. Next, in agreement with their scrambled localization in the psoriatic keratinocyte, and in contrast with normal epidermal cells, both $\beta_{1}$ and $\beta_{4}$ heterodimers acquire a functional role in mediating keratinocyte adhesion in vitro. In fact, antibodies to both heterodimers inhibit adhesion, thus suggesting that either integrins become essential for psoriatic keratinocyte attachment.

The last alteration concerns the $\alpha_{5} \beta_{1}$ fibronectin receptor. Several authors have reported that the $\alpha_{5} \beta_{1}$ integrin is not expressed by normal human adult epidermis $(13,15,33-36)$. Recent data showed that $\alpha_{5} \beta_{1}$ is expressed only by fetal or neonatal epidermis $(33,37)$. In cultured human keratinocytes $\alpha_{5} \beta_{1}$ has been shown to be expressed and finely regulated during the keratinocyte differentiation program (38). However, contrasting data exist in terms of its cytoskeleton association and adhesive functions since $\alpha_{5} \beta_{1}$ has been reported to be poorly and diffusely expressed on the keratinocyte plasma membrane (17) and not organized in defined adhesive structures (9), or expressed in focal contacts mediating keratinocyte adhesion (15, 18). Recently, the clustering of the fibronectin receptor in defined adhesive structures has been correlated with keratinocyte migration during wound healing (39).

By immunocytochemistry in situ, we show that $\alpha_{5} \beta_{1}$ is undetectable in normal adult skin, while it is clearly expressed in sections of psoriatic epidermis and by psoriatic keratinocytes in vitro. In our experimental conditions, cultured normal adult keratinocytes express the $\alpha_{5}$ mRNA and the $\alpha_{5}$ protein itself is barely exposed on the adult epidermal cell plasma membrane. However, by immunocytochemistry, we never observed $\alpha_{5} \beta_{1}$ organized in adhesion structures in normal adult keratinocytes in primary or secondary culture $(9,11$, and Results). Interestingly, in psoriatic keratinocytes, the prototype fibronectin receptor is organized in defined structures such as focal contacts. Based on these data, it is tempting to speculate that hyperproliferative conditions such as: (a) the fetal/neonatal environment, psoriasis, skin cancer, and wound healing in vivo; $(b)$ nonphysiological culture conditions such as low $\mathrm{Ca}^{2+}$ media; (c) stress situations such as high number of cell passages (De Luca, M., G. Pellegrini, S. Bondanza, O. Cremona, P. Savoia, R. Cancedda, and P. C. Marchisio, submitted for publication). (d) exposure of keratinocytes to a fibronectin-rich environment such as those occurring during epidermal wound healing (39, 53) (De Luca, M., G. Pellegrini, S. Bondanza, O. Cremona, $P$ Savoia, R. Cancedda, and P. C. Marchisio, submitted for publication) all might alter integrin polarization and/or trigger the organization of the fibronectin receptor in defined adhesive structures $(31,54)$. In fact a functionally comparable mechanism exists for platelets $(55,56)$, for the fast activation-regulated function of $\alpha_{5} \beta_{1}$ in CD4+ resting human T cells (57) and for the fibronectin dependent activation of the $\mathrm{Na}^{+} / \mathrm{H}^{+}$antiporter in mouse fibroblasts (58). This might be true also for parameters other than $\alpha_{5} \beta_{1}$-cytoskeleton interaction. It will be interesting to investigate whether, in psoriasis, a possible alteration of the extracellular matrix composition might account for by the induction of $\alpha_{5} \beta_{1}$ clustering. In fact, an increased synthesis of fibronectin in psoriatic epidermis has already been reported $(59,60)$. Similar alterations in integrin polarization and cytoskeleton association have been noted in neoplastic keratinocytes from basal and squamous cell carcinomas (Savoia, P., O. Cremona, and P. C. Marchisio, manuscript in preparation) and in virally transformed keratinocytes (13), and might explain the contrasting data existing in the literature concerning the polarization and cytoskeleton organization of the $\beta_{1}$ integrins as well as the differences of integrin organization existing between the epidermis in vivo and keratinocytes in vitro $(9,11-13,15-18,33-37)$.

It is important to note that integrin alterations are evident, both in vivo and in vitro. Furthermore, recognizable integrin alterations occur also in keratinocytes from the uninvolved skin of psoriatic patients. To our knowledge this is the first defined biochemical defect identified in the asymptomatic skin of psoriatic patients. Even more interestingly, in a recent case, foreskin keratinocytes obtained from a 6-yr-old boy and originally meant for use as a control strain, displayed loss of integrin polarity in culture. The same donor eventually developed a form of psoriasis a few months later. In addition, both parents were affected by the disease (De Luca, M., and P. C. Marchisio, unpublished data). This suggests the possibility of using the disturbance of integrin polarity as a screening approach in family studies of the genetic component of psoriasis as well as a predictive marker of the disease. Although we cannot prove that this adhesive disturbance is the initial cause of the disease, it is tempting to speculate that it may have a major role in the pathogenesis of psoriasis.

\section{Acknowledgments}

We thank Prof. A. T. Franzi (University of Genova, Italy) for help with Fig. 1.

Supported by Progetto Finalizzato "Biotecnologie e Biostrumentazione," Consiglio Nazionale delle Ricerche (CNR, Rome), by Associa- 
zione Italiana per la Ricerca sul Cancro (AIRC, Milano), and by Ministero per l'Università e la Ricerca Scientifica e Tecnologica (MURST, Rome).

\section{References}

1. Watt, F. M. 1989. Terminal differentiation of epidermal keratinocytes. Curr. Opin. Cell Biol. 6:1107-1115.

2. Abelda, S. M., and C. A. Buck. 1990. Integrins and other cell adhesion molecules. FASEB (Fed. Am. Soc. Exp. Biol.) J. 4:2869-2880.

3. Hynes, R. O. 1987. Integrins: a family of cell surface receptors. Cell. 48:549-554.

4. Buck, C. A., and A. F. Horwitz. 1987. Cell surface receptors for extracellular matrix molecules. Annu. Rev. Cell Biol. 3:179-205.

5. Edelman, G. M. 1986. Cell adhesion molecules in the regulation of animal form and tissue pattern. Annu. Rev. Cell Biol. 2:81-116.

6. Ekblom, P., D. Westweber, and R. Kemler. 1986. Cell-matrix interactions and cell adhesion during development. Annu. Rev. Cell Biol. 2:27-47.

7. Ruoslahti, E. 1991. Integrins. J. Clin. Invest. 87:1-5.

8. Ruoslahti, E., and M. D. Pierschbacher. 1987. New perspectives in cell adhesion: RGD and integrins. Science (Wash. DC). 238:491-497.

9. Marchisio, P.C., S. Bondanza, O. Cremona, R. Cancedda, and M. De Luca. 1991. Polarized expression of integrin receptors $\left(\alpha_{6} \beta_{4}, \alpha_{2} \beta_{1}, \alpha_{3} \beta_{1}\right.$, and $\left.\alpha_{4} \beta_{5}\right)$ and their relationship with the cytoskeleton and basement membrane matrix in cultured human keratinocytes. J. Cell Biol. 112:761-773.

10. Lampugnani, M. G., M. Resnati, E. Dejana, and P. C. Marchisio. 1991 The role of integrins in the maintenance of endothelial monolayer integrity. $J$. Cell Biol. 112:479-490.

11. De Luca, M., R. N. Tamura, S. Kajiji, S. Bondanza, P. Rossino, R. Cancedda, P. C. Marchisio, and V. Quaranta. 1990. Polarized integrin mediates human keratinocyte adhesion to basal lamina. Proc. Natl. Acad. Sci. USA. 87:68886892 .

12. Marchisio, P. C., R. Cancedda, and M. De Luca. 1990. Structural and functional studies of integrin receptors in cultured human keratinocytes. Cell Differ. Dev. 32:355-360.

13. Ryynänen, J., S. Jaakkola, E. Engvall, J. Peltonen, and J. Uitto. 1991. Expression of $\beta_{4}$ integrins in human skin: comparison of epidermal distribution with $\beta_{1}$-integrin epitopes, and modulation by calcium and vitamin $D_{3}$ in cultured keratinocytes. J. Invest. Dermatol. 97:562-567.

14. Stepp, M. A., S. Spurr-Michaud, A. Tisdale, J. Elwell, and I. K. Gipson. 1990. $\alpha_{6} \beta_{4}$ integrin heterodimer is a component of hemidesmosomes. Proc. Natl. Acad. Sci. USA. 87:8970-8974.

15. Carter, W. G., P. Kaur, S. G. Gil, P. J. Gahr, and E. A. Wayner, 1990 Distinct functions for integrins $\alpha_{3} \beta_{1}$ in focal adhesions and $\alpha_{6} \beta_{4} /$ bullous pemphigoid antigen in a new stable anchoring contact (SAC) of keratinocytes: relation to hemidesmosomes. J. Cell Biol. 111:3141-3154.

16. Sonnenberg, A., J. Calafat, H. Janssen, H. Daams, L. M. H. van der Raaij-Helmer, R. Falcioni, S. J. Kennel, J. D. Aplin, J. Baker, M. Loizidou, and D. Garrod. 1991. Integrin $\alpha_{\epsilon} \beta_{4}$ complex is located in hemidesmosomes, suggesting a major role in epidermal cell-basement membrane adhesion. J. Cell Biol. 113:907-917.

17. Larjava, H., J. Peltonen, S. K. Akiyama, S. S. Yamada, H. R. Gralnick, J. Uitto, and K. M. Yamada. 1990. Novel function of $\beta_{1}$ integrins in keratinocyte cell-cell adhesion. J. Cell Biol. 110:803-815.

18. Carter, W. G., E. A. Wayner, T. S. Bouchard, and P. Kaur. 1990. The role of integrins $\alpha_{2} \beta_{1}$ and $\alpha_{3} \beta_{1}$ in cell-cell and cell-substrate adhesion of human epidermal cells. J. Cell Biol. 110:1387-1404.

19. Rheinwald, J. G., and H. Green. 1975. Serial cultivation of strains of human epidermal keratinocytes: the formation of keratinizing colonies from single cells. Cell. 6:331-344.

20. Green, H., O. Kehinde, and J. Thomas. 1979. Growth of cultured human epidermal cells into multiple epithelia suitable for grafting. Proc. Natl. Acad. Sci. USA. 76:5665-5668.

21. De Luca, M., F. D'Anna, S. Bondanza, A. T. Franzi, and R. Cancedda. 1988. Human epithelial cells induce human melanocyte growth in vitro but only skin keratinocytes regulate its proper differentiation in the absence of dermis. $J$. Cell Biol. 107:1919-1926.

22. Gallico, G. G., N. E. O'Connor, C. C. Compton, O. Kehinde, and H. Green. 1984. Permanent coverage of large burn wounds with autologous cultured human epithelium. N. Engl. J. Med. 311:448-451.

23. De Luca, M. E. Albanese, S. Bondanza, M. Megna, L. Ugozzoli, F. Molina, R. Cancedda, P. L. Santi, M. Bormioli, M. Stella, and G. Magliacani. 1989. A multicentre experience in the treatment of burns with autologous and allogeneic cultured epithelium, fresh or preserved in a frozen state. Burns. 15:303-309.

24. De Luca, M., E. Albanese, M. Megna, R. Cancedda, P. E. Mangiante, A. Cadoni, and A. T. Franzi. 1990. Evidence that human oral epithelium reconstituted in vitro and transplanted onto patients with defects in the oral mucosa retains properties of the original donor site. Transplantation (Baltimore). 50:454459.

25. Romagnoli, G., M. De Luca, F. Faranda, R. Bandelloni, A. T. Franzi, F. Cataliotti, and R. Cancedda. 1990. Treatment of posterior hypospadias by the autologous graft of cultured urethral epithelium. N. Engl. J. Med. 323:527-530.

26. Pinkus, H., and A. H. Mehregan. 1966. The primary histologic lesion of seborrheic dermatitis and psoriasis. J. Invest. Dermatol. 46:109-116.

27. Orfanos, C. E., G. Schaumburg-Lever, G. Mahrle, and W. F. Lever. 1973. Alterations of cell surfaces as a pathogenetic factor in psoriasis. Arch. Dermatol. 107:38-46.

28. Lever, W. F., and G. Schaumburg-Lever. 1990. Histopathology of the skin. J. B. Lippincott Co., Hagerstown, MD. 156-164.

29. Kajiji, S., R. N. Tamura, and V. Quaranta. 1989. A novel integrin $\left(\alpha E \beta_{4}\right)$ from human epithelial cells suggest a fourth family of integrin adhesion receptors. EMBO (Eur. Mol. Biol. Organ.) J. 8:673-680.

30. Chomczynski, P., and N. Sacchi. 1987. Single-step method of RNA isolation by acid guanidium thiocynate-phenol-chloroform extraction. Anal. Biochem. 162:156-159.

31. Dejana, E., S. Colella, M. Abbadini, M. Gaboli, and P. C. Marchisio. 1988. Fibronectin and vitronectin regulate the organization of Arg-Gly-Asp adhesion receptor at focal contacts of cultured human endothelial cells. J. Cell Biol. 107:1215-1223.

32. Tamura, R. N., C. Rozzo, L. Starr, J. Chambers, L. F. Reichardt, H. M. Cooper, and V. Quaranta. 1990. Epithelial integrin $\alpha_{6} \beta_{4}:$ complete primary structure of $\alpha_{6}$ and variant forms of $\beta_{4}$. J. Cell Biol. 111:1593-1604.

33. Konter, U., I. Kellner, C. E. Klein, R. Kaufmann, V. Mielke, and W. Sterry. 1989. Adhesion molecule mapping in normal human skin. Arch. Dermatol. Res. 281:454-462.

34. Peltonen, J., H. Larjava, S. Jaakkola, H. R. Gralnick, S. K. Akiyama, S. S. Yamada, K. M. Yamada, and J. Uitto. 1989. Localization of integrin receptors for fibronectin, collagen, and laminin in human skin. Variable expression in basal and squamous cell carcinomas. J. Clin. Invest. 84:1916-1923.

35. Klein, C. E., T. Steinmayer, J. M. Mattes, R. Kaufmann, and L. Weber. 1990. Integrins of normal human epidermis: differential expression, synthesis and molecular structure, Br.J. Dermatol. 123:171-178.

36. Nazzaro, V., E. Berti, A. Cerri, A. Brusasco, R. Cavalli, and R. Caputo. 1990. Expression of integrins in junctional and dystrophic epidermolysis bullosa. J. Invest. Dermatol. 95:60-64.

37. Hertle, M. D., J. C. Adams, and F. M. Watt. 1991. Integrin expression during human epidermal development in vivo and in vitro. Development (Camb.). 112:193-206.

38. Adams, J. C., and F. M. Watt. 1990. Changes in keratinocyte adhesion during terminal differentiation: reduction in fibronectin binding precedes $\alpha_{s} \beta_{1}$ integrin loss from the cell surface. Cell. 63:425-435.

39. Guo, M. L. T. Kim, S. K. Akiyama, H. R. Gralnick, K. M. Yamada, and F. Grinnell. 1991. Altered processing of integrin receptors during keratinocyte activation. Exp. Cell Res. 195:315-322.

40. Luger, T. A., and T. Schwartz. 1990. Evidence for an epidermal cytokine network. J. Invest. Dermatol. 95:100S-104S.

41. Di Marco, E., P. C. Marchisio, S. Bondanza, A. T. Franzi, R. Cancedda, and M. De Luca. 1991. Growth-regulated synthesis and secretion of biologically active nerve growth factor by human keratinocytes. J. Biol. Chem. 266:2171821722.

42. Krueger, J. G., J. F. Krane, D. M. Carter, and A. B. Gottlieb. 1990. Role of growth factors, cytokines, and their receptors in the pathogenesis of psoriasis. $J$. Invest. Dermatol. 94:135S-140S.

43. Elder, J. T., G. J. Fisher, P. B. Lindquist, G. L. Bennet, M. R. Pittelkow, R. J. Coffey, L. Ellingsworth, R. Derynck, and J. J. Voorhees. 1989. Overexpression of transforming growth factor alpha in psoriatic epidermis. Science (Wash. DC). 243:811-814.

44. Turbitt, M. L., R. J. Akhurst, S. I. White, and R. M. MacKie. 1990. Localization of elevated transforming growth factor-alpha in psoriatic epidermis. J. Invest. Dermatol. 95:229-232.

45. Kane, J. C., A. M. Knapp, J. N. Mansbridge, and P. C. Hanawalt. 1990. Transforming growth factor-beta 1 localization in normal and psoriatic epidermal keratinocytes in situ. J. Cell. Physiol. 144:144-150.

46. Cooper, K. D., C. Hammerberg, O. Baadsgaard, J. T. Elder, L. S. Chan, D. N. Sauder, J. J. Voorhees, and G. Fisher. 1990. IL-1 activity is reduced in psoriatic skin. Decreased IL-1 alpha and increased nonfunctional IL-1 beta. $J$. Immunol. 144:4593-4603.

47. Prens, E. P., K. Benne, J. van Damme, M. Bakkus, K. Brakel, R. Benner, and T. van Joost. 1990. Interleukin-1 and interleukin-6 in psoriasis. J. Invest. Dermatol. 95:121S-124S.

48. Nickoloff, B. J., and C. E. M. Griffiths. 1990. Lymphocyte trafficking in psoriasis: a new perspective emphasizing the dermal dendrocyte with active dermal recruitment mediated via endothelial cells followed by intraepidermal T-cell activation. J. Invest. Dermatol. 95:35S-37S.

49. King, L. E., R. E. Gates, C. M. Stoscheck, and L. B. Nanney. 1990. The EGF/TGF $\alpha$ receptor in skin. J. Invest. Dermatol. 94:164S-170S. 
50. Elder, J. T., A. Tavakkol, S. B. Klein, M. E. Zeigler, M. Wicha, and J. J. Voorhees. 1990. Protooncogene expression in normal and psoriatic skin. J. In vest. Dermatol. 94:19-25.

51. Fisher, J. G., H. S. Talwar, A. Tavakkol, J. Esmann, J. J. Baldassare, J. T. Elder, C. E. M. Griffiths, O. Baadsgaard, K. D. Cooper, and J. J. Voorhees. 1990. Phosphoinositide-mediated signal transduction in normal and psoriatic epidermis. J. Invest. Dermatol. 95:15S-17S.

52. Gaidano, G., L. Bergui, M. Schena, M. Gaboli, O. Cremona, P. C. Marchisio, and F. Calligaris-Cappio. 1990. Integrin distribution and cytoskeleton organization in normal and malignant monocytes. Leukemia (Baltimore). 4:682-687.

53. Clark, R. A. 1990. Fibronectin matrix deposition and fibronectin recepto expression in healing and normal skin. J. Invest. Dermatol. 94:128S-134S.

54. Roman, J., R. M. LaChance, T. J. Broekelmann, C. J. R. Kennedy, E. A. Wayner, W. G. Carter, and J. A. McDonald. 1989. The fibronectin receptor is organized by extracellular matrix fibronectin: implications for oncogenic transformation and for cell recognition of fibronectin matrices. J. Cell Biol. 108:25292543.
55. Marguerie, G. A., E. F. Plow, and T. S. Edgington. 1979. Human platelets possess an inducible and saturable receptor specific for fibrinogen. J. Biol. Chem 254:5357-5363.

56. Du, X., E. F. Plow, A. L. Frelinger, T. E. O'Toole, J. C. Loftus, and M. H. Ginsberg. 1991. Ligands "activate" integrin $\alpha_{m b} \beta_{3}$ (platelet GIIb-IIIa). Cell. 65:409-416.

57. Shimizu, Y., G. A. Van Seventer, K. J. Horgan, and S. Shaw. 1990 Regulated expression and binding of three VLA $\left(\beta_{1}\right)$ integrin receptors of $\mathrm{T}$ cell. Nature (Lond.). 345:250-253.

58. Schwartz, M. A., C. Lechene, and D. E. Ingbar. 1991. Insoluble fibronectin activates the $\mathrm{Na} / \mathrm{H}$ antiporter by clustering and immobilizing integrin $\alpha_{s} \beta_{1}$, independent of cell shape. Proc. Natl. Acad. Sci. USA. 88:7849-7853.

59. Bernard, B. A., S. M. Robinson, S. Vandaele, and J. N. Mansbridge. 1985. Abnormal maturation pathway of keratinocytes in psoriatic skin. Br. J. Dermatol. 112:647-653.

60. Fyrand, O. 1979. Studies on fibronectin in the skin. II. Indirect immunofluorescence studies in psoriasis vulgaris. Arch. Dermatol. Res. 226:33-44. 